\title{
Feminine Authorship and Women's Education in Citius, Altius, Fortius Journal (1959-1976)
}

\section{Emanuele Isidori ${ }^{1}$, María Perrino Peña ${ }^{2}$, Miguel Vicente Pedraz ${ }^{2}$}

\author{
${ }^{1}$ University of Rome “Foro Italico”, Italy \\ ${ }^{2}$ University of León, Spain
}

\begin{abstract}
This article approaches women's scientific and humanistic production in the journal Citius, Altius, Fortius. Based on several previous bibliometric and thematic studies - where the journal's epistemological orientation and ideological and editorial trajectory were analyzed - this research aims to highlight and analyze the role of women who collaborate in the journal in order to set these representations. The article deals particularly with women's conceptions as physical activity practitioners.

Descriptive, comparative and content analysis techniques have been used, emphasizing ideological discourse. In conclusion we point out the disproportion of women's scientific production, which shows males' dominant position in physical activity studies at that time.

The very female authors' perspective about sportswomen is in fact an accommodative, and even a servile, position towards the dominant physicaleducative and sport discourses.

sport, physical education, ideology, woman, feminism
\end{abstract}

\section{Introduction}

The editorial initiative of Citius, Altius, Fortius, active during almost twenty years within the Francoist regime, was one of the few cultural and formative proposals in the field of physical culture and sport in Spain at that time. The journal was designed and directed by Miguel Piernavieja del Pozo, a recognized Spanish historian, and José María Cagigal Gutiérrez, a very prestigious sport philosopher and pedagogue. Later on, in 1959, its date of appearance on the publishing market, the journal reached an outstanding position in the field of human sciences, which was defined by a social, economic, and political context that did not offer many possibilities for those projects that did not perfectly fit into the dictatorial regime's propaganda device.

The support and interest showed by José Antonio Elola Olaso, National Delegate of Sport in those years, was decisive. He did not turn the publication in a political instrument serving Franco's regime, but supported the participation of international collaborators with different perspectives and sensitivities in relation to the expected views spread along the Spanish physical and ideological realms 
at that moment. It supposed a real opening and a revolutionary factor within the humanistic, sports, and physical education studies.

The journal was considered an emblematic publication in this field, and it achieved, according to Olivera (2006), the $36^{\text {th }}$ position in a study made by the Documentation Department of the Deutsche Hochschule für Korperkultur from Leipzig in 1966. Included in the study were the 184 most important scientific and cultural journals that specialized in physical and sport education. Citius, Altius, Fortius was the only Spanish publication incorporated in this study. Thus, the few significant citations and lack of research developed about this journal highlighting its technical-scientific, educational, and informative relevance until present are quite surprising.

Besides the specific objectives proposed in this article and detailed below, we attempt, if not to cover this void, to at least contribute to recognize and assess the relevance of the project, which lasted almost 20 years, done by those professionals who were dedicated in one or in other way to sport and physical education research, especially from a humanistic approach.

\section{Objectives}

This research is included in a wider comprehensive study about the Citius, Altius, Fortius journal, and aims to identify the main epistemological variables of this publication, categorize its authorship, and define the editorial policy. This is done through critical analysis, comparative analysis, and ideological discourse analysis applied to articles and essays included in the journal.

Based on that study and some of the previously published results (Perrino \& Vicente 2008a, 2008b, 2010), the degree, significance, relevance, and transcendence of feminine scientific production published in Citius, Altius, Fortius will be emphasized here after selecting and appropriately analysing the significant articles. The features analyzed include: authorship characteristics, number of women collaborating in the journal, number of articles written by women, impact of women's articles in relation to the whole, topics studied by women, as well as their individual position in respect to the journal's prevailing editorial policy.

Specifically, the conceptual and ideological representations of physical education and sport femininity embedded in the journal are analysed through women's collaborations:

- to deduce women's and sportswomen's concepts and representations that appeared in the Citius, Altius, Fortius journal by means of scientific-technical production analysis of women collaborations;

- to assess from an epistemological and ideological point of view the physical education, physical activities, and sports promoted and recommended by and to women in the Citius, Altius, Fortius journal;

- to check if feminine contributions to the journal could suppose a technical and ideological opening in relation to gender issues within the physical and sports culture existing within Franco's regime in Spain; or, on the contrary, if they contributed to legitimate established ideas about male domination.

\section{Method}

Qualitative methodology using descriptive, comparative, and content analysis techniques, and emphasizing ideological discourse interpretation, has been applied. However, a previous documentary classification and indexation process based on Perrino and Vicente (2008a, 2008b) was carried out to objectify the data collected. This preliminary process is included within the content analysis techniques. According to Pinto Molina's work (1996, p. 301) the objectification process is defined as a "cognitive process of documentary content inspection, description and representation", and developed in three different phases: reading or comprehension, analysis (selection and interpretation), and 
synthesis. Thus, it is considered a multiparadigmatic process, using several techniques such as classification, indexation, and abstracting, and interpretation (Molina 2002, pp. 444-445).

The aforementioned bibliometric study has been reviewed and actualized for the present research in order to adapt scientific production variables to specific objectives set here. In this manner, common variables and bibliometric analysis techniques have been used (Pitchard 1969, López, Piñero \& Terrada 1992, Ferreiro Aláez 1993, López Yepes 2002). Moreover, examples of bibliometric studies applied to periodicals (Peñaranda Ortega 2003) and research patterns applied to scientific production in the field of education (Pérez Serrano 2007) have also been considered.

Particular aspects of some authors' works, such as the grade of productivity of collaborators (NP, or Lotka's Law), the canopy of topics, the total number of authors, as well as their gender, nationality, frequency of collaboration, to name a few, could be deduced from the results of scientific production analysis. According to the concept of categorization defined by Bardin (1986) or Krippendorff (1990), and comparing the results obtained from scientific production analysis, the content of journal articles and essays was examined using the scientific reading method. In this way, some categories were initially established (Topic 1) following very restrictive inclusion criteria, but gathering whole studies published in the journal. Each category was divided and specified in subcategories (Topic 2) to confirm the hierarchy and presence of the different types of content through a simple tree system. The predominant scientific orientation of the editorial policy was deduced by means of these strategies (Perrino Peña \& Vicente Pedraz 2008a, 2008b). The approach of ideological journals, as well as and sport conceptions in Spain, was analyzed through scientific-humanistic production in later research (Perrino Peña \& Vicente Pedraz 2010).

Table 1 . Thematic repertory with feminine authorship detailed by categories

\begin{tabular}{|c|c|c|c|c|}
\hline Topic 1 & Topic 2 & $\begin{array}{c}\text { Articles } \\
\text { (Number \& } \\
\text { Frequency) }\end{array}$ & $\begin{array}{c}\text { Woman } \\
\text { thematic } \\
\text { (Number \& } \\
\text { Frequency) }\end{array}$ & $\begin{array}{c}\text { Woman author } \\
\text { (Number) }\end{array}$ \\
\hline HISTORY & Civilizations Hist. & $37 / 17,7 \%$ & $3 / 8,1 \%$ & 2 \\
\hline \multirow{3}{*}{ Total: $82\left(39{ }^{\prime} 23 \%\right)$} & Sport Hist. & 27 / 12,9\% & $2 / 7,4 \%$ & 1 \\
\hline & Physical Education Hist. & $7 / 3,34 \%$ & 0 & 0 \\
\hline & Biographies & $11 / 5,26 \%$ & 0 & 0 \\
\hline PHILOSOPHY & Sport Philosophy & $19 / 9,09 \%$ & 0 & 0 \\
\hline \multirow[t]{3}{*}{ Total: 45(21'53\%) } & Olimpic Phil. & $7 / 3,34 \%$ & 0 & 0 \\
\hline & Physical Education Phil. & $12 / 5,74 \%$ & 0 & 0 \\
\hline & Phycology & $7 / 3,34 \%$ & 0 & 0 \\
\hline LINGUISTICS / & Semantics & $10 / 4,78 \%$ & 0 & 0 \\
\hline PHILOLOGY & Literature & $19 / 9,09 \%$ & $1 / 5 ’ 2 \%$ & 1 \\
\hline \multirow[t]{2}{*}{ Total: $42(20 ’ 09 \%)$} & Law & $11 / 5,26 \%$ & 0 & 0 \\
\hline & Bibliographies & $2 / 0,95 \%$ & 0 & 0 \\
\hline $\begin{array}{l}\text { SOCIOLOGY } \\
\text { Total: } 19\left(9^{\prime} 09 \%\right)\end{array}$ & Sport Sociology & $19 / 9,09 \%$ & $1 / 5,2 \%$ & 1 \\
\hline EDUCATION & Phys. Ed. Didactics & $7 / 3,34 \%$ & $1 / 14,2 \%$ & 1 \\
\hline Total: $11(5,26 \%)$ & Phys. Ed. Research & $4 / 1,91 \%$ & 0 & 0 \\
\hline $\begin{array}{l}\text { MEDICINE } \\
\text { Total: } 6\left(2{ }^{\prime} 87 \%\right)\end{array}$ & $\begin{array}{l}\text { Physiology of Physical } \\
\text { Activity }\end{array}$ & $6 / 2,87 \%$ & $4 / 66,6 \%$ & 1 \\
\hline Total absolute & & 209 & $11 / 5,2 \%$ & 7 \\
\hline
\end{tabular}

Regarding the perspective of feminine authors - the aim of this study - journal articles written by women were selected and revised. The analysis of aspects directly related to feminine physical practices were pointed out in the scientific reading of these articles in order to infer woman's imagery in physical culture at that time.

Seven articles written by five women were considered in total. Tables 1 and 2 show an overview of journal content. Table 1 resumes the tree system with thematic markers of the above-mentioned 
studies (columns 1 and 2, respectively); frequency of topic appearance (column 3); total number of articles dedicated to women or feminity (column 4); and finally, the number of women writers appearing in each category (column 5). Table 2 depicts several aspects of the scientific productivity, such as the authorship in relation to gender (columns 1,2, and 3); total articles written by men/women (columns 4, 5, and 6); and finally, articles that deals with women and sport thematic in relation to the total.

Table 2. Relative summary of the authorship and the articles in relation to gender

\begin{tabular}{lcccccc}
\hline $\begin{array}{l}\text { Authors } \\
\text { (Total) }\end{array}$ & $\begin{array}{c}\text { Authors } \\
\text { (Men) }\end{array}$ & $\begin{array}{c}\text { Authors } \\
\text { (Women) }\end{array}$ & $\begin{array}{c}\text { Articles } \\
\text { (Total) }\end{array}$ & $\begin{array}{c}\text { Articles } \\
\text { (by men) }\end{array}$ & $\begin{array}{c}\text { Articles } \\
\text { (by women) }\end{array}$ & $\begin{array}{c}\text { Art. Women } \\
\text { \& Sport } \\
\text { Thematic } \\
\text { (Total) }\end{array}$ \\
\hline $\mathbf{1 3 9}$ & 134 & 5 & $\mathbf{2 0 9}$ & 202 & 7 & 11 \\
$\mathbf{1 0 0 \%}$ & $96^{\prime} 4 \%$ & $3 ' 59 \%$ & $\mathbf{1 0 0 \%}$ & $96 ' 65 \%$ & $3 ' 35 \%$ & $5^{\prime} 26 \%$ \\
\hline
\end{tabular}

Among the multiple and available secondary sources, the descriptive and interpretative research about works that were published in that period by official agencies and ideological state mechanisms for legitimizing the secondary position of a woman and her subordinate character in sports practise, as well as in relation to the field of physical education, were consulted.

In this respect, the socio-historical analysis about physical education and sport in Franco's time that was developed by Betancor and Vilanou (1995) should be highlighted. Under a descriptive approach, Pastor Pradillo's study (1997) should be also mentioned. He elaborated a historical description along the last century of training used for physical education teachers, including some interesting reviews about feminine physical education. Research done by Puig (1995), Girela (1999), González Aja (2002), and Manrique Arribas (2008), which includes theses and conclusions in relation to women's participation or representation in physical-educative and sport spheres during this period, has been also considered.

The orientation that could be deduced, implicitly or explicitly, from each of the selected articles was investigated to discover the underlying ideology in representations of women. The most relevant pedagogic or sport ideas in relation to gender differences were identified first. Those aspects were assessed according to ideological discourse analysis methodology (Van Dijk 1996, 2005, Wodak \& Meyer 2001, Rodríguez-Zamora 2004) through dissonance contrast with more or less dominant official and/or popular ideas. Later, those positions that could be considered as a support, or in collusion with, masculinist perspectives of physical culture have been pointed out. Put differently, the idea of physical practices embedded on the gender power structures that emphasized the aesthetic value, maternity, body refinement, or any other common feminine feature within women's practises has contributed historically to encourage the ideological principles in traditional Spanish society.

\section{Interpretation/ discussion}

The quantitative analysis (Tables 1 and 2) shows that, proportionally, the woman hardly exists in the pages of Citius, Altius, Fortius. There is hardly any female representation on the staff of collaborators, and after a scientific reading of the journal articles, we can also say that on most of the occasions female gender, the female figure, female nature, female physical and psychological features, typical female behaviour or women - as historiographical characters - are subsumed in the generic man. On the other hand, on the few occasions in which the subject "woman" is specifically referred to - as a sociological figure - or there is a reference to differential aspects of gender emphasising female characters/characteristics, the interpretation of the theoretical production throws a vision, protective most of the times, of the patriarchal features, more legitimist than critical of women status, and consequently, of the gender relationships. This subject is treated in the same proportion by female and 
male columnists - five of each gender - by only 10 out of 139 people in the team of collaborators in the journal during its existence.

Analysing the predominant thematic in which women appear, it doesn't seem that femininity is a proper matter for men except for those times when it is about offering a medical vision of the female body and a historical vision of sports practices fulfilled by women. In the first case, the "difficulties", "lacks", "risks", "inconveniences" of some practices - the sports ones - which were considered more appropriate for male bodies are emphasized; the high percentage of biomedical studies about women out of the total articles written in this thematic area - four out of six - is surprising, although there is only one written by a female author. In the historiographic studies, also according to a certain guardian vision of women, femininity is treated to highlight the epic character of some sports episodes where they are treated as "strange" main characters in a world that was naturally considered manly.

It is necessary to point out that, of the five women who wrote in the journal - clearly a revealing number of the few possibilities of taking part in this kind of forums - they do it almost exclusively about subjects referred to women: five out of seven articles. In this respect, it can be deduced that, if the matter of women is mainly a subject of women, "woman" and "femininity" were, moreover, almost the only thematic which they wrote about. Further, it is important to observe the almost absolute absence of the articles in which the tone can be considered critical concerning the power of male culture, or a feminist tone that, obviously, represents a socio-political and cultural reality inscrutable to any claims or declaration when it comes to established patriarchal values. The only one that could be qualified as that, and not exactly progressive, is the one signed by Dzidra Rozitis de Piernavieja, Miguel Piernavieja's wife, one of the journal's directors.

The most detailed collaborator is Janine Assa, with three written articles, two of which specifically referred to women, "Female Olympics", (Assa 1960) and "Women and Sport in the Antiquity" (Assa 1963). In the first one, the author is trying to determine whether or not there is a difference between the female Olympic games of antiquity and the modern ones. Focusing on the latter, she points out that, in spite of Coubertin's negative support of female Olympic participation, the Olympic Games:

"haven't stopped being modified, and the olympic ideal has been adapted to the collectivity or mass notion which has obliged to make room for new sport activities, team sports and, finally, the admission of the new chosen ones from society: women" (1960, p. 400).

However, before being openly considered an achievement of equality, the author seems to doubt, when it comes to the role, that women's roles represented in this manly world may be conditioned by the stereotypes of that time:

"It was, of course, an eccentricity of some women that were bored, but the innovators set a precedent [...]. The "femme-garçonne", the woman "equal to a man" tried to reassure herself by trying to fulfil a whole theory in serious disadvantages [...], the evolution of ideas and customs has been so remarkable that- except for rare occasions- the fact of seeing a woman in sport clothes (sometimes unfortunate) doesn't call anybody's attention anymore" (1960, pp. 400-401).

"marriage, family maternity and the fact that all these don't stop them from doing olympic activities" (1960, p. 403).

The same doubt can be observed in the second study that has been mentioned (Assa, 1963), where if at the start there aren't any doubts about the social status of women:

“Women have access to a status of a more or less brilliant men's companion, but, if there is an area where it is usual to insist on their weakness and darkening it is, in no doubts, in sport" (1963, p. 429), 
there is no lack of critical references to the dominant cultural model, especially noticeable in the field of physical culture, physical education, and sport:

"What Christians mainly stigmatized in the classic civilization was, besides gladiator shows, the degenerate of body worship which came along with the thermal baths abuse. This bond between hygiene and body culture, which were two ways to give importance to the human body, had serious consequences. All the Christian conception which was imposed in the Medieval Europe came from the idea that body culture drives to sin or it is a sin in itself; the opposition considering body culture every physical activity which was not part of the exercise that every day life required; from were, as well as that, there was a return to the formal outfits, full, heavy, complex, embarrassing, dresses which would have to be worn for a long time in female physical education and sport".

The third and last article by Assa (1961), "The Position of Sport in Horace's Work" lacks every mention to women themselves. It is one of the few studies carried out by women, which is not about "women".

One of the most relevant articles in the journal under a woman authorship might be "Female Gymnastics" by Jesusa de Granda y Lahín (1963) - original: in Crónica del Sport, 1893 - not as relevant for its content but because of what the author represents - a teacher in the Central Gymnastics school in Madrid before the school closed down in 1892 - and, above all else, because of the opportunity or topicality that the authors of Citius, Altius, Fortius saw in her pages, they decided to reprint it in 1963. As it is expressed in the journal's note:

"it is not easy to judge doctrines that, if more stable in the philosophical and pedagogical aspects, have been, however, well superseded in the technical and scientific aspects" (1963, pp. 473-note).

Something really surprising, if we take into account the philosophic-pedagogical doctrine in discussion:

"[women] more than men, need to be directed in the exercise that is going to develop and educate their bodies. Firstly, because of their high mission in nature, to become mothers; secondly, because their being weakened by the lack of a former education, needs special care to make up for the loss that they have suffered for centuries in an ignorant routine and blind fanaticism. [...] they need gymnastics that start by healing their anaemia, their hysteria, all the conditions that have trapped their fragile bodies annihilating and hindering their souls development" (1963, p. 479).

"because a woman, as no other being, has in her nature the harmony that governs the whole universe. This is why female gymnastics must not require great muscular effort, but regular movements in her organism. It must not be similar to male gymnastics, as the aim of them both is different. Female gymnastics must be run by the woman herself and not by men" (1963, p. 480).

This is like that in such a way that:

"it comes to fill in emptiness in our society that no one was able to carry out. She comes to redeem her sex in the chains that make her more miserable, those that turn her into a slave of her anaemic and rachitic body" (1963, p. 480).

The sharpest article form the point of view of the gender relation is one that Dzidra Rozitis de Piernavieja wrote (1962), whose article "Femininity and Sport" is the only one for which it can be said takes a feminist stance; an ambiguous one, but certainly, for that time, controversially feminist. The text begins by pointing out that sport hasn't meant anything good for women, it has even been detrimental to them: 
"nobody has analyzed properly the real impact that sport has caused in women's life. What has sport given to women? And what can it still give? The answer can only be one and categorical: nothing good but the opposite" (1962, p. 401).

The feminism of Dzidra Rozitis de Piernavieja is moving obscurely between the reactionary claim of the female courtesy rights, which are considered in decline, and the right to equal treatment that sport restricts due to gender reasons.

This was, next to expressions that seem to miss a protective masculinity:

"it is precisely sport which has knocked down the myth of female fragility. Sport, if we don't do something about it, is going to end up with the last remainders of masculine conscience that women need protection because of being a weak being” (1962, p. 404),

or also:

"thanks to sport, men have dispossessed us of all the mystery, base of our power, and are at the same time removed from our slavery. All the companionship in the field of sport is a male trick to keep on hitting our yoke" (1962, p. 407),

we can also find expressions that highlight the struggle for equality against the one that men were conspiring by physical education and sport:

"While we [...] have followed our husbands by bicycle, on foot or hopping in a manageable way, they have displayed an inappropriate slyness [...]. They tell us the advantages of physical education and sport; but, actually, they go around mining more and more the last remainders of our power [...] Let's not forget even for a little while that physical education, according to the concept created by men, gets you ready for life, to fight and battle in life [...] Do you realize how threatened our position is?" (1962, pp. 408-409).

The speech finishes with an ironic harangue to mothers so that the prevent their daughters from doing sport that, depending on the point of view, could be considered ultraconservative, or, to the contrary, be qualified as transgressor; in any case, surprising in the context or the publication:

“Let's defend ourselves! By all means! Let's avoid that our daughters do sport! [...] Let's let men keep waging wars and discovering continents and planets, giving triple jumps and enacting laws but for us and because of us, never against us. Let's fight for female rights and male duties!" (1962, p. 409).

The article by Anna Maria di Giorgio (1963) "Female sport and aesthetics" - which comes from the medical Italian magazine Bolletino Acc. Med. Pistoese, XXV (1955) - is the only female cooperation that tackles women physical practises from a hygienic-philosophical perspective that nevertheless doesn't leave aside questions related to the "harmonic development of the several functions and of the female body proportions" (Giorgio 1963, p. 481); and not so much to discuss or refute the traditional postulates surrounding female body nature and its "inferiority" in sports but to authenticate them. Based on studies of the time, the existing differences between a sportsman and sportswoman stand out through physiological values and physical presentation addressed to corroborate such inferiority:

"The importance of women reactions turns out to be, as a whole, inferior to the one of men even in sports signs that doesn't require an excessive performance" (1963, p. 490).

"the perseverance of different values between both sexes would really show the functional differences that can't be over come by means of training [...] Breathing and circulatory reflexes which are necessary to make up for this cost, although also very fast in women, are more limited that in men, and although physical exercise leads to important improvements, the efficiency never gets to be identical to the one of men" (1963, p. 493). 
To conclude, according to the male paradigm at the time, which considered that adequate female physical activity is one that develops female functions and aesthetics correctly, should be a moderate and not very constant activity:

"As a consequence, for sport to continue being a precious means of aesthetic somatic development and for the harmonic integration of the vegetative functions, it would be appropriate to avoid activities that force the organism in an excessive or a too repeated way" (1963, p. 494).

It is necessary to notice that this is the only article with biomedical content written by a woman which, once it is looked up the general relationship of the subject that the journal is dealing with, highlights the different scientific orientation of men and women, being much higher the proportion of published biomedical studies in men. María Concepción Blasco (1976), whose article is entitled "Hunting in Levantine Spanish cave art", already in the last stage of the journal, is the only author who writes about non-female subjects although, while accepting the assertion that women tend to write about women in Citius, Altius, Fortius, Blasco seems to see herself forced to refer to the subject by deducing that prehistorical hunting activity was carried out exclusively by men, as there are no images of women hunting in any of the collections of cave art:

"it is precise to point out that hunting was exclusively a male duty as there are no female representations in relation to this activity” (1976, p. 81).

\section{Conclusions}

The scarce female production in the journal Citius, Altius, Fortius, which shows the dominant position of men in the technical scientific and humanistic fields of sport at the time when the journal was published, can be deduced from the quantitative analysis.

Patriarchal values, and consequently, some tutelary prevention - sometimes even distrust towards sense and effects of feminine sports practise can be noticed by this quantitative analysis, as well as the extracted inferences from the scientific reading of the selected articles.

An attitude that could be qualified as masculinist is still alive in the sport and physical education vision, with ancestral cultural roots that seem to be shared by other international authors, and enhanced by the political and cultural ideas of the dictatorship.

Socio-historical studies predominate, although the thematic orientation is varied, with the only appearance of one biomedical study. Men and women's different scientific orientation is also emphasized in this question, as the proportion of biomedical researches concerning men is considerably higher in the whole journal.

The idealist conception of physical exercise (moderate, sensible, and well-directed) that praises the physiological, hygienic, psychological, aesthetical, and social benefits for women, always eluding some sport disciplines and competition in general, is added to the women's tutelary representation that we can usually extract from this journal, and particularly from female authors.

This journal is not especially critical with the prevailing conception of women, nor with restrictions and prohibitions imposed on her, which means a certain agreement with these ideas.

In any case, the opening to the contribution of recognized, prestigious intellectuals in such fields as philosophy, history, sociology, psychology, and others, in some cases women cultivated on the subject, whose views, if not critical reviews, at least done from an intellectual distance, meant encouragement to a theoretical approach to physical education and sport, very unusual in the publications of that time. In this sense, and considering both the quantitative and qualitative importance of the contribution of foreign researchers, the journal could be considered as a physical culture study reference point. Regarding this, if all the education - particularly body education constituted one more possibility of ideological control serving Franco's dictatorial regime, Citius, 
Altius, Fortius's discourse about physical education could be considered, even with all terminological concessions to the political administration that protected it, epistemologically innovative and pedagogically compromised, with an open and transforming view.

Related to female physical education, progress - or a political "release", as Manrique (2008, p. 324) calls it - is experimented with more rational and technical approaches, where opening positions can be included in some studies in Citius, Altius, Fortius.

\section{REFERENCES}

Bardin, L. (1986). El análisis de contenido /The analysis of content/. Madrid: Akal.

Betancor León, M.A. \& Vilanou Torrado, C. (1995). Historia de la Educación Física y el deporte a través de los textos /History of the Physical Education and the sport across the texts/. Barcelona: PPU.

Ferreiro Aláez, L. (1993). Bibliometría: análisis bivariante/Bibliometric: analysis bivariante/. Madrid: Elypasa.

Gilera Rejón, M.J. (1999). La actividad física y deportiva de las mujeres en la historia. VI Simposium Historia de la Educación Física /The physical and sports activity of the women in the history/ (pp. 77-88). Universidad of Salamanca.

González Aja, T. (2002). La política deportiva en España durante la República y el Franquismo. In T. González Aja, P. Arnaud, (et al.) (Eds.), Sport y autoritarismos: la utilización del deporte por el comunismo y el fascismo /The sports politics in Spain during the Republic and the Franco's regimel (pp.169-201). Madrid: Alianza Editorial.

Krippendorff, K. (1990). Metodología de análisis de contenido: teoría y práctica /Methodology of analysis of content: theory and practicel. Barcelona: Paidós.

López Piñero, J.M. \& Terrada, M.L. (1992). Los indicadores bibliométricos y la evaluación de la actividad médico-científica (III). Los indicadores de producción, circulación, dispersión, consumo de la información y repercussion /Bibliometric indicators and evaluation of medical and scientific activity (III). The indicators of production, circulation, dispersion, consumption and impact information/. Medicina Clínica - Barcelona, 98 (4), $142-148$.

López Yepes, J. (coord.) (2002). Manual de Ciencias de la Documentación /Manual Documentation Sciences/. Madrid: Pirámide.

Manrique Arribas, J.C. (2008). Mujer y educación fisica durante el franquismo/Women and physical education during the Franco/. Valladolid: Universidad of Valladolid.

Olivera Betrán, J. (2006). José María Cagigal y su contribución al humanismo deportivo /José María Cagigal humanism and its contribution to sport/. Revista Internacional de Sociología, vol. LXIV (44), Mayo-Agosto, 207235.

Pastor Pradillo, J.L. (1997). El espacio profesional de la educación fisica en España: génesis y formación (18831961) /Professional space for physical education in Spain: genesis and training (1883-1961)/. Madrid: Universidad of Alcalá de Henares.

Peñaranda Ortega, M. (2003). La colaboración científica en la psicología social y de la personalidad: Análisis bibliométrico del Journal of Personality and Social Psychology /Scientific collaboration in social psychology and personality: Bibliometric analysis of the Journal of Personality and Social Psychology/. Tesis Doctoral, Departamento de Psicología Básica y Metodología, Universidad of Murcia.

Pérez Serrano, G. (2007). Análisis bibliométrico en educación. Incidencia en la calidad universitaria /Bibliometric analysis in education. Impact on university quality/. Research project, not published. Ref.: EA 2003-2007. Retrieved on 22 April 2009, from http://www.micinn.es/ univ/html/informes/estudios_analisis /resultados_2003/EA2003-0007/EA2003-0007.pdf.

Perrino Peña, M. \& Vicente Pedraz, M. (2008a). Repertorio temático de Citius, Altius, Fortius. Revista de estudios deportivos (1959-1976) /Thematic repertoire of Citius, Altius, Fortius. Journal of sports studies (19591976)/. Actas del V Congreso de la Asociación Española de Ciencias del Deporte. Universidad of León.

Perrino Peña, M. \& Vicente Pedraz, M. (2008b). Revista de estudios deportivos: Citius, Altius, Fortius (19591976). Aproximación bibliométrica de los autores. IJournal of sports studies: Citius, Altius, Fortius (19591976). Bibliometric approach the authors/. Actas del V Congreso de la Asociación Española de Ciencias del Deporte. Universidad of León.

Perrino Peña, M. \& Vicente Pedraz, M. (2010). La concepción del deporte y de la educación corporal a través de la revista Citius, Altius, Fortius. Lealtades y disidencias en la España de los años 60 y 70 /The design of sport and physical education through the journal Citius, Altius, Fortius. Loyalties and dissidence in Spain in the 60 and 70/. In J. Martí \& Y. Aixelá (Eds.), El cuerpo: objeto y sujeto de las ciencias humanas y sociales /The body: 
object and subject of the human and social sciences/. Barcelona: CSIC.

Pinto Molina, M. (1996). Análisis documental de contenido /Content analysis of documents/. In J. López Yepes (Ed.), Manual de información y documentación /Manual of information and documentation/ (pp. 300-323). Madrid: Pirámide.

Pinto Molina, M. (2002). Análisis documental de contenido /Content analysis of documents/. In J. López Yepes (coord.) (Ed.), Manual de Ciencias de la Documentación /Manual of Sciences of the Documentation/ (pp. 419447). Madrid: Pirámide.

Pitchard, A. (1969). Statistical bibliography on bibliometrics? Journal of Documentation, 25(4), 348-349.

Puig Roig, M.C. (1995). Análisis de la política educativa en educación fisica durante el franquismo. La Ley de Educación Física de 1961. IEducational Policy Analysis in physical education under Franco. Physical Education Act of 1961\%. Actas del II Congreso de Ciencias del Deporte, la Educación Física y la Recreación. Vol. I., (196-207). Lleida, INEFC.

Rodríguez-Zamora, J.M. (2004). Estructura semántica y análisis ideológico/Semantic structure and ideological analysis/. Filología y Lingüistica. 30(2), 155-169.

Van Dijk, T.A. (1996). Análisis del discurso ideológico/Ideological discourse analysis/. Versión, 6, 15-43.

Van Dijk, T.A. (2005). Ideología y análisis del discurso /Ideological discourse analysis/. Utopía y Praxis Latinoamericana / Afio, 10(29), 9-36.

Wodak, R. \& Meyer, M. (2001). Methods of critical discourse analysis. London: Sage.

\section{Sources: Citius, Altius, Fortius}

Assa, J. (1960). El Olimpismo femenino /The women's Olympic/. Citius, Altius, Fortius. Tomo II (3), 397-403.

Assa, J. (1961). El lugar del deporte en la obra de Horacio /The place of sport in the work of Horace/. Citius, Altius, Fortius. Tomo III, (2), 213-225.

Assa, J. (1963). La mujer y el deporte en la Antigüedad/The Women and Sport in the Ancient/. Citius, Altius, Fortius. Tomo V, (4), 429-444.

Blasco, M.C. (1976). La caza en el arte rupestre levantino español/Hunting in Spanish Levantine rock art/. Citius, Altius, Fortius. Tomo VII-VIII, 53-88.

de Granda, J. (1963). La gimnástica femenina /The women's gymnastics/. Citius, Altius, Fortius. Tomo V, (4), 473-480.

de Piernavieja, D. (1962). Femineidad y deporte /Femininity and sport/. Citius, Altius, Fortius. Tomo IV, (3), 401-409.

di Giorgio, A.M. (1976). El deporte femenino y la estética /Women's sport and aesthetics/. Citius, Altius, Fortius. Tomo $V$, (4), 483-494.

AUTHOR'S ADDRESS: $\quad$ Emanuele Isidori University of Rome "Foro Italico"

Piazza L. De Bosis, 15

00135 Roma, Italy

Email: emanuele.isidori@uniroma4.it 